\title{
Physicochemical Comparison of Precipitated Calcium \\ Carbonate for Different Configurations of a Biogas Upgrading \\ Unit.
}

Francisco M. Baena-Moreno ${ }^{a, b}$, Cameron Alexander Hurd Price ${ }^{b}$, Estelle le Saché ${ }^{b}$, Laura Pastor-Pérez $^{\mathrm{b}, \mathrm{c}}$, Daniel Sebastia-Saez ${ }^{\mathrm{b}}$, T. R. Reina $^{\mathrm{b}}$.

a Chemical and Environmental Engineering Department, Technical School of Engineering, University of Seville, C/ Camino de los Descubrimientos $s / n$, Sevilla 41092, Spain

${ }^{b}$ Department of Chemical and Process Engineering, University of Surrey, GU2 7XH Guildford, United Kingdom

${ }^{c}$ Laboratorio de Materiales Avanzados, Departamento de Química Inorgánica Instituto Universitario de Materiales de Alicante Universidad de Alicante, Apartado 99, E03080

Alicante, Spain

${ }^{*}$ Corresponding author.

E-mail address: fbaena2@us.es (Francisco M. Baena-Moreno)

\begin{abstract}
BACKGROUND: This paper presents a physicochemical comparison of the solid products obtained from two alternative processes that recycle waste sodium carbonate
\end{abstract}

This article has been accepted for publication and undergone full peer review but has not been through the copyediting, typesetting, pagination and proofreading process which may lead to differences between this version and the Version of Record. Please cite this article as doi: $10.1002 /$ jctb.6013

This article is protected by copyright. All rights reserved. 
$\left(\mathrm{Na}_{2} \mathrm{CO}_{3}\right)$ solution, which is produced following the absorption of $\mathrm{CO}_{2}$ in a biogasupgrading unit. Chemical regeneration processes offer an attractive alternative to the energetically demanding standard physical methods. In the first process, sodium hydroxide $(\mathrm{NaOH})$ is regenerated as a precipitate from the chemical reaction of $\mathrm{Na}_{2} \mathrm{CO}_{3}$ with calcium hydroxide $\left(\mathrm{Ca}(\mathrm{OH})_{2}\right)$. The second process shows a path to obtain a valuable sodium chloride $(\mathrm{NaCl})$ and Calcium carbonate $\left(\mathrm{CaCO}_{3}\right)$ rich brine from calcium chloride $\left(\mathrm{CaCl}_{2}\right)$ acting as a precipitant agent. In both processes, Precipitated Calcium Carbonate (PCC) is obtained as the most valuable by-product, but with varying properties due to the different origin.

RESULTS: The purpose of this work is to analyse physicochemically both variations of PCCs obtained and examining the differences between these solid samples in order to determine which method produces more desirable characteristics in the final product. To this end, FTIR, Raman, XRD and SEM were employed as characterization methods. The results reflect that both PCCs have a calcite crystal structure, or morph, being as both PCC products originate from $\mathrm{CaCl}_{2}$ that is more similar to commercial calcium carbonate calcite.

CONCLUSION: These results confirmed that a pure $\mathrm{CaCO}_{3}$ valuable by-product can be obtained from a biogas upgrading unit with several industrial applications.

Keywords: Biogas; Carbon Capture; Carbon Utilisation; Chemical Analysis; Green Chemistry; Precipitation

\section{Introduction}


The need to combine renewable energies with current fossil fuels to reduce pollution is one of the topics most discussed by the scientific community ${ }^{1-3}$. Biogas, mainly composed of carbon dioxide $\left(\mathrm{CO}_{2}\right)$ and methane $\left(\mathrm{CH}_{4}\right)$, is one of the most studied sources of renewable energy ${ }^{4-8}$. Biogas comes from the anaerobic digestion of different types of biomass. To be used as a substitute for natural gas, biogas should be upgraded to obtain biomethane, which can be injected into the natural gas distribution network. Additionally, biomethane can be used as fuel or as a base material for the synthesis of methanol ${ }^{9-11}$. The major contaminant within biogas that is formed during its synthesis, is $\mathrm{CO}_{2}$. As such, the removal of this contaminant and the resultant upgrading of biogas is a topic of considerable research by several authors ${ }^{12-14}$. Among these techniques, $\mathrm{CO}_{2}$ absorption seems to be the most promising since high capture efficiencies can be achieved ${ }^{15,16}$. For instance, some authors employed monoethanolamine (MEA) or piperazine (PZ) as solvents, achieving $90 \% \mathrm{CO}_{2}$ capture efficiency ${ }^{17-21}$. On the other hand, caustics solvents such as sodium hydroxide $(\mathrm{NaOH})$ or potassium hydroxide $(\mathrm{KOH})$ were employed towards carbon sequestration showing similar results ${ }^{22-25}$. $\mathrm{NaOH}$ does not present degradation as amines do, which can produce emissions with an elevated toxicity. Moreover the formation and harmful effects of nitrosamines and nitramines known as potential carcinogenic compounds is characteristic of amines, which does not occur by the employed of caustic solvents ${ }^{26}$. Furthermore, caustic solvents are cheaper and more abundant than MEA or PZ, but the main problem with caustic solvents compared to these traditional solvents is the high energy penalty in the regeneration stage via physical methods ${ }^{11,27}$. For this reason, many researchers investigate the regeneration via chemical reaction in a recyclable process, as shown in Figure 1, in order to balance the energy penalty with 
favorable cost ${ }^{13,25,28-32}$. However, these processes did not achieve technical feasibility due to the relatively low regeneration efficiencies (50-60\%) seen by the use of waste

solutions with high $\mathrm{Ca}(\mathrm{OH})_{2}-\mathrm{Mg}(\mathrm{OH})_{2}$ content ${ }^{13,22,25,33}$. In our previous work ${ }^{12}$ a method for biogas upgrading and precipitated calcium carbonate (PCC) production was investigated, obtaining promising results for further research.

Figure 1. Process for biogas upgrading and PCC production.

In this work, $\mathrm{CO}_{2}$ was removed from biogas through sodium hydroxide $(\mathrm{NaOH})$ absorption in a packed tower, according to equation (1). In order to regenerate the $\mathrm{NaOH}$ and make the process economically viable, a precipitation step was undertaken to produce PCC (equation (2)), employing calcium hydroxide $\left(\mathrm{Ca}(\mathrm{OH})_{2}\right)$ as a precipitating agent, as an improved method against weaker hydroxide waste solutions, that were employed previously.

$2 \mathrm{NaOH}(a q)+\mathrm{CO}_{2}(g) \rightarrow+\mathrm{Na}_{2} \mathrm{CO}_{3}+\mathrm{H}_{2} \mathrm{O}$

$\mathrm{Na}_{2} \mathrm{CO}_{3}(a q)+\mathrm{Ca}(\mathrm{OH})_{2}(s) \rightarrow 2 \mathrm{NaOH}(a q)+\mathrm{CaCO}_{3}(s)$

The aim of our previous study was to optimize the reaction parameters to achieve a reasonable $\mathrm{NaOH}$ regeneration efficiency, as well as to obtain a high product quality, which could be sold to improve the overall economic performance of the process. Nevertheless, after studying the psychochemical characteristics of PCC, it was concluded that an impure material was obtained under the conditions imposed. However, to achieve higher purity PCC from the chosen concentration of precipitating agent required higher temperature or pressure that would in turn increase the energy penalty of the whole process. Therefore manipulation of the precipitating agent 
presents a much more viable solution. In this sense, calcium chloride $\left(\mathrm{CaCl}_{2}\right)$ is an attractive candidate towards improving PCC purity, since it presents a higher solubility in water than $\mathrm{Ca}(\mathrm{OH})_{2}$. The benefit of this higher solubility is that the co-precipitation of $\mathrm{CaCl}_{2}$ with $\mathrm{PCC}$ as it remains in the aqueous solution. The reaction between $\mathrm{Na}_{2} \mathrm{CO}_{3}$ and $\mathrm{CaCl}_{2}$ is defined by equation (3).

$\mathrm{Na}_{2} \mathrm{CO}_{3}(a q)+\mathrm{CaCl}_{2}(s) \rightarrow 2 \mathrm{NaCl}(a q)+\mathrm{CaCO}_{3}(s)$

However, the use of $\mathrm{CaCl}_{2}$ produces $\mathrm{NaCl}$ rather than the desired regeneration of $\mathrm{NaOH}$. Since the feed of fresh solvent is crucial to maintain the economy of the process, it could be obtained from caustic waste solutions by means of Bipolar Membrane Electrodialysis (BMED). This technique has been widely studied, reporting promising results; as well as benefitting from a cost effective economic balance and positive life cycle assessment when employing renewable energy ${ }^{34-38}$. Figure 2 represents a schema of the proposed innovative process. In this way, high-purity PCC and sodium chloride $(\mathrm{NaCl})$ brine are obtained as valuable products instead of $\mathrm{NaOH}$, making this a potential process for closing the $\mathrm{CO}_{2}$ capture and utilization cycle.

Figure 2. Innovative proposed process for biogas upgrading and PCC production.

Therefore, the purpose of this new work was to establish a physicochemical comparison for PCC production between calcium chloride $\left(\mathrm{CaCl}_{2}\right)$ and/or $\mathrm{Ca}(\mathrm{OH})_{2}$ as precipitants to evaluate if the product obtained meets our hypothesis towards high purity PCC production. To define the physicochemical properties of both types of formed carbonates, Fourier-transform infrared spectroscopy (FTIR), Raman spectroscopy, X-ray Diffraction (XRD) and Scanning electron microscopy (SEM) were employed. Should the results prove the production of high purity PCC, this process 
would allow further research to focus on a potential industrial application of this innovative process.

\section{Materials and Methods}

\subsection{Materials}

Chemicals used in the experiments $\left(\mathrm{Ca}(\mathrm{OH})_{2}, \mathrm{Na}_{2} \mathrm{CO}_{3}, \mathrm{CaCl}_{2}, \mathrm{CaCO}_{3}\right)$ were provided by PanReac-AppliChem (pure-grade or pharma-grade, 99\% purity, Barcelona, Spain).

\section{Table 1. Specifications of the chemicals.}

\subsection{Process conditions and Physicochemical characterization measurements}

The process description was previously addressed in our previous work ${ }^{39}$. In brief, first the reactant solutions and equipment were prepared. After these steps, the precipitation reaction was carried out and once finished the solid products obtained were filtered and separated for analyzing. The reaction conditions were set at $50^{\circ} \mathrm{C}, 1.2$ mol Ca per mol $\mathrm{Na}_{2} \mathrm{CO}_{3}$ and 30 minutes for reaction time. After the precipitation experiments, the solid obtained by filtration was dried at $105^{\circ} \mathrm{C}$ overnight in order to characterize the samples by means of FTIR, Raman, XRD and SEM.

A Perkin Elmer FTIR BX spectrometer (Waltham, Massachusetts, United States) was used for performing the attenuated total reflection Fourier transform infrared spectroscopy in the powders (ATR-FTIR, uncertainty 2\%). Background subtracted spectra of the raw and the treated samples were collected at room temperature by coadding 32 scans at $4 \mathrm{~cm}^{-1}$ resolution in transmittance mode. Data were baseline corrected using Spectrum $5^{\mathrm{TM}}$ software. Raman measurements of the powders samples were recorded using a Thermo DXR2 spectrometer (Waltham, 
Massachusetts, United States) equipped with a Leica DMLM microscope (uncertainty $1 \%)$. The wavelength of applied excitation line was $532 \mathrm{~nm}$ ion laser and $50 x$ objective of 8-mm optical was used to focus the depolarized laser beam on a sport of about $3 \mu \mathrm{m}$ in diameter.

XRD analysis was completed using an X'Pert Pro PANalytical instrument (Malvern, United Kingdom) using a step size $0.05^{\circ}, 450$ time per step over a range of $10-90^{\circ}$ at 40 $\mathrm{mA}$ and $45 \mathrm{kV}$ using Cu Ka radiation $(\lambda=0.154 \mathrm{~nm}$, uncertainty $1 \%)$.

A JEOL JSM6400 (Akishima, Tokyo, Japan) operated at $20 \mathrm{KV}$ equipped with energy dispersive X-ray spectroscopy (EDX) and a wavelength dispersive X-ray spectroscopy (WDS) system was used for the microstructural/chemical characterization (SEM with EDS and WDS).

\section{Results}

\section{FTIR spectrum}

The first step of the physicochemical comparison was to corroborate the formation of the carbonate phase in the collected samples. For this purpose, Figure 3 represents both FTIR spectrum for PCC from $\mathrm{Ca}(\mathrm{OH})_{2}$ and $\mathrm{CaCl}_{2}$ as precipitant agents in comparison with a commercial $\mathrm{CaCO}_{3}$ solid sample.

Figure 3. FTIR spectra for obtained samples.

Typically, a strong band of $\mathrm{CaCO}_{3}$ spectra appears at around $1400-1500 \mathrm{~cm}^{-1}$ as well as a weaker peaks at $876 \mathrm{~cm}^{-1}$ and $715 \mathrm{~cm}^{-1} 40$. These are easily identified in every spectra of Figure 1, so it is possible to conclude that the carbonate phase is presented in both studied samples. According to the vibration bands at $715 \mathrm{~cm}^{-1}$ are indicative 
that calcite is the predominant crystal type in the investigated $\mathrm{CaCO}_{3}$ samples, although it will be confirmed later by XRD ${ }^{41}$. Previously, in ${ }^{40}$, FTIR spectra for different $\mathrm{CaCO}_{3}-\mathrm{Ca}(\mathrm{OH})_{2}$ mixtures were studied, obtaining strong vibrations at around $3600 \mathrm{~cm}^{-1}$ which are characteristic of hydroxyl groups. Indeed, only when pure $\mathrm{CaCO}_{3}$ was measured, the produced spectra did not show this peak, inferring the peak at this value suggests the presence of hydroxide ions from $\mathrm{Ca}(\mathrm{OH})_{2}$. In the Figure 3 inset, the data corroborates that there is no presence of these hydroxides, meaning that the purity of the PCC samples obtained is relatively high. Nevertheless, is not possible by means of this technique to distinguish the complete absence of $\mathrm{Ca}(\mathrm{OH})_{2}$ in the represented spectrum. There may be some remnants of $\mathrm{Ca}(\mathrm{OH})_{2}$ in the samples that would appear also at approximately $1400-1500 \mathrm{~cm}^{-1}$, as in $\mathrm{CaCO}_{3}$ spectra ${ }^{40}$. It is also possible to confirm that there is no $\mathrm{CaCl}_{2}$ remaining in the inset of Figure 3 , as there is no peak at $3200 \mathrm{~cm}^{-1}$, characteristic of $\mathrm{CaCl}_{2}$.

Table 2. FTIR vibration bands for the chemicals studied.

\section{Raman measurements}

To distinguish possible residual $\mathrm{Ca}(\mathrm{OH})_{2}$, Raman spectroscopy was employed. Furthermore, this technique was useful to corroborate a carbonate phase in the collected samples, which can be seen in Figure 4 that represents both the PCC Raman spectrum from $\mathrm{Ca}(\mathrm{OH})_{2}$ and $\mathrm{CaCl}_{2}$ precipitant agents in comparison with a commercial $\mathrm{CaCO}_{3}$ solid sample.

Figure 4. Raman spectra for obtained samples. 
$\mathrm{CaCO}_{3}$ shows a monoclinic structure that belongs to the $\mathrm{P} 21 / \mathrm{c}$ group ${ }^{42}$. The main characteristic band of $\mathrm{CaCO}_{3}$ polymorphs appears at around $1100 \mathrm{~cm}^{-1}$ and ca. 700 $\mathrm{cm}^{-1}$ and is typically ascribed to this monoclinic type of structure ${ }^{42,43}$. Figure 4 shows that these two peaks are presented in both PCC spectra for PCC from $\mathrm{Ca}(\mathrm{OH})_{2}$ and $\mathrm{CaCl}_{2}$, confirming the successful precipitation process due to the formation of the carbonate phase. The appearance of a band at $400 \mathrm{~cm}^{-1}$ and $1086 \mathrm{~cm}^{-1}$ are characteristic of $\mathrm{Ca}(\mathrm{OH})_{2}$ that must be due to a small amount of $\mathrm{Ca}(\mathrm{OH})_{2}$ remaining present in $\mathrm{PCC}$ from $\mathrm{Ca}(\mathrm{OH})_{2}$ sample as this does not appear in the $\mathrm{PCC}$ from $\mathrm{CaCl}_{2}$ spectrum. This was distinguished by the Raman vibration mode at $c a .400 \mathrm{~cm}^{-1}$, which belongs to the most characteristic intense band of commercial $\mathrm{Ca}(\mathrm{OH})_{2}$ as confirmation of our previous hypothesis ${ }^{44}$. The absence of this peak in PCC from $\mathrm{CaCl}_{2}$ spectra confirms a pure $\mathrm{CaCO}_{3}$ employing $\mathrm{CaCl}_{2}$ as a precipitant agent, proving that by using this innovative process, it is possible to obtain PCC with a purity of $100 \%$ by removing $\mathrm{CO}_{2}$ from biogas streams.

Table 3. Raman bands for the chemicals studied.

\section{$X R D$ analysis}

Once $\mathrm{CaCO}_{3}$ was confirmed as the only species for $\mathrm{PCC}$ from $\mathrm{CaCl}_{2}$ and predominant species for $\mathrm{Ca}(\mathrm{OH})_{2}$ by both FTIR and Raman measurements, XRD analysis was carried out to distinguish which crystal morph of $\mathrm{CaCO}_{3}$ has been obtained. The future use of the final $\mathrm{CaCO}_{3}$ obtained depends on the morph, so that makes the crystal structure of the final product extremely important for both precipitant agents. There are three types of $\mathrm{CaCO}_{3}$ crystal morphs: calcite, vaterite, and aragonite ${ }^{45}$. In terms of thermodynamics, the most stable form is calcite, followed by aragonite with vaterite 
being the least stable ${ }^{46}$. Figure 5 represents XRD patterns of the PCC obtained from both sources in comparison with commercial $\mathrm{CaCO}_{3}$ calcite.

Figure 5. XRD spectra for obtained samples.

The analysis of the obtained XRD patterns, confirms that the calcite morph has been produced, the peaks being in accordance with previous references studied ${ }^{46,47}$. The main peaks of calcite appear at $28^{\circ}, 39^{\circ}, 43^{\circ}$ and $48^{\circ}$. All of these peaks can be seen in both XRD patterns of $\mathrm{PCC}$ from $\mathrm{Ca}(\mathrm{OH})_{2}$ and $\mathrm{CaCl}_{2}$. Nevertheless, it seems that PCC from $\mathrm{CaCl}_{2}$ pattern is more consistent with commercial calcite than $\mathrm{PCC}$ from $\mathrm{Ca}(\mathrm{OH})_{2}$, due to the strong presence of $\mathrm{Ca}(\mathrm{OH})_{2}$ within the sample, the peaks for which appear at $18^{\circ}, 28^{\circ}, 34^{\circ}, 51^{\circ}$ and $55^{\circ}{ }^{48}$. Characteristic $\mathrm{CaCl}_{2}$ peaks appear at $13^{\circ}$ and $18^{\circ} 49$ and as can be seen on the relevant XRD plot in figure 5 , there is no presence of any residual $\mathrm{CaCl}_{2}$ as the mentioned peaks are not present. These results agree with both Raman and FTIR analyses presented previously in this work.

Table 4. XRD peaks for the chemicals studied.

\section{SEM images}

Calcite has five different structural shapes: rhombohedral, rhomboscalenohedral, scalenohedral, scalenorhombohedral, and spheroidal ${ }^{50}$. Rhombohedral or scalenohedral shapes are widely employed as filler in paper industry, due to an enhancement produced in the optical properties of paper sheets ${ }^{50}$. Confirming the different shapes of the obtained samples is therefore very important when considering future applications and is possible through SEM analysis. SEM images are useful to gain further insights on the structure of the samples. Multiple images of the obtained 
samples were taken to ensure homogeneity. Figures 6 and 7, showcase representative examples of the SEM micrographs. Again the presence of $\mathrm{CaCO}_{3}$ is confirmed with the typical morphology of calcite as previously observed by Altiner et al. ${ }^{43}$. In their study, several PCC structures are shown and strictly compared, obtaining similar results to those presented in this work regarding the morphology of the different solids obtained. As can be seen in Figure 6, $\mathrm{PCC}$ from $\mathrm{Ca}(\mathrm{OH})_{2}$ presents a polymorph form with a mixture of different morphologies. On the contrary, Figure 7 shows a rhombohedral form of the particles, again highlighting the purity of the $\mathrm{CaCO}_{3}$ obtained in the form of calcite and making the product very valuable from a commercial point of view discussed above.

Figure 6. SEM image for PCC from $\mathrm{Ca}(\mathrm{OH})_{2}$.

Figure 7. SEM image for $P C C$ from $\mathrm{CaCl}_{2}$.

\section{Conclusions and future remarks}

After sequestrating $\mathrm{CO}_{2}$ from a biogas stream by employing $\mathrm{NaOH}$ as solvent and later $\mathrm{NaOH}$ regeneration or transformation to valuable products via chemical reaction with calcium compounds, in this paper the main psychochemical characteristics of PCC from two different chemicals are studied. The results reveal that a more valuable byproduct can be achieve by using $\mathrm{CaCl}_{2}$ as precipitant agent instead of $\mathrm{Ca}(\mathrm{OH})_{2}$. Additionally this innovative process could replace the energetically demanding methods employed to regenerate carbonated compounds after $\mathrm{CO}_{2}$ absorption. 
Raman study shows that a carbonate phase is produced in both solid samples, as well as a small quantity of $\mathrm{Ca}(\mathrm{OH})_{2}$ unreacted when PCC comes from this source. Moreover, these results are confirmed by FTIR analyses. XRD provided information about the type of PCC obtained, being calcite in both materials, but seeming more similar PCC from $\mathrm{CaCl}_{2}$ to commercial calcite than $\mathrm{PCC}$ from $\mathrm{Ca}(\mathrm{OH})_{2}$. Finally, SEM images show the majority presence of calcite on the precipitated material, comparing with previous references. Interestingly, it was found rhombohedral form when reacting with $\mathrm{CaCl}_{2}$, while more polymorph structure is shown when employing $\mathrm{Ca}(\mathrm{OH})_{2}$.

Overall this study reveals the suitability of $\mathrm{CaCl}_{2}$ as a precipitating and its advantages over $\mathrm{Ca}(\mathrm{OH})_{2}$ to generate a pure $\mathrm{CaCO}_{3}$ final product. This study has therefore set the basis for future process up scaling. Ongoing efforts in our group are devoted to further explore the impact of the proposed process in biogas upgrading units at commercial and pilot scale.

\section{Acknowledgments and Funding}

This work was supported by University of Seville through V PPIT-US. Financial support for this work was also provided by the EPSRC grant EP/R512904/1 as well as the Royal Society Research Grant RSGR1180353. This work was also partially sponsored by the $\mathrm{CO}_{2}$ Chem UK through the EPSRC grant EP/P026435/1. Furthermore this work was supported by EMASESA through NURECCO2 project and Corporación Tecnológica de Andalucía (CTA).

\section{Figures}




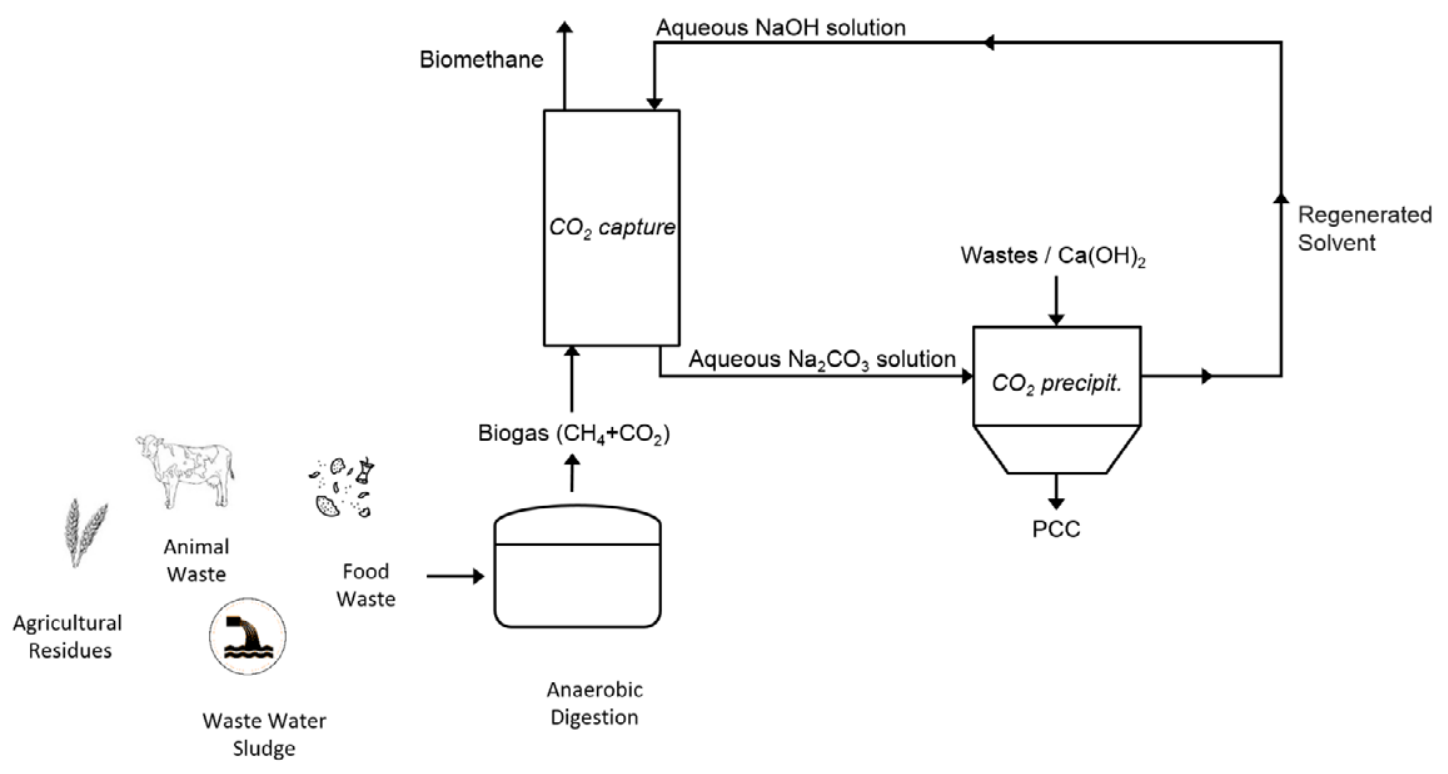

Figure 1. Process for biogas upgrading and PCC production. 


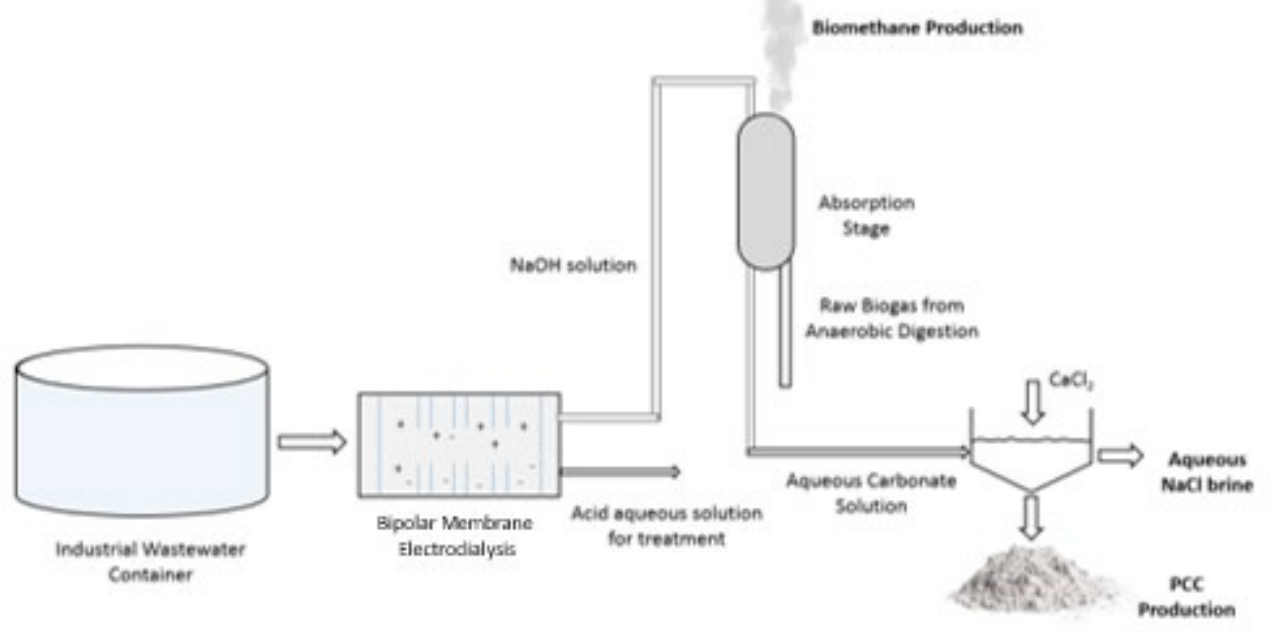

Figure 2. Innovative proposed process for biogas upgrading and PCC production. 


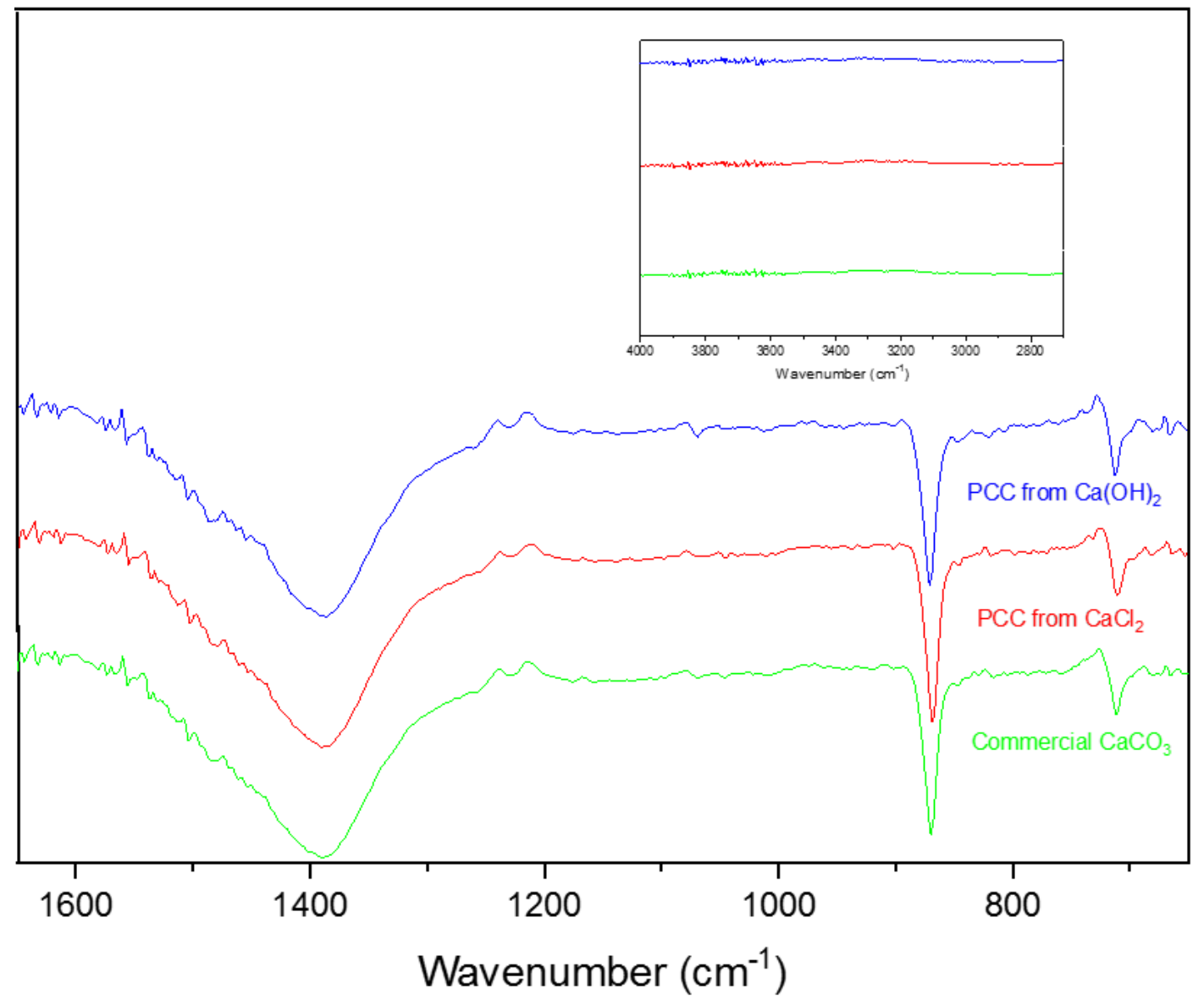

Figure 3. FTIR spectra for obtained samples. 


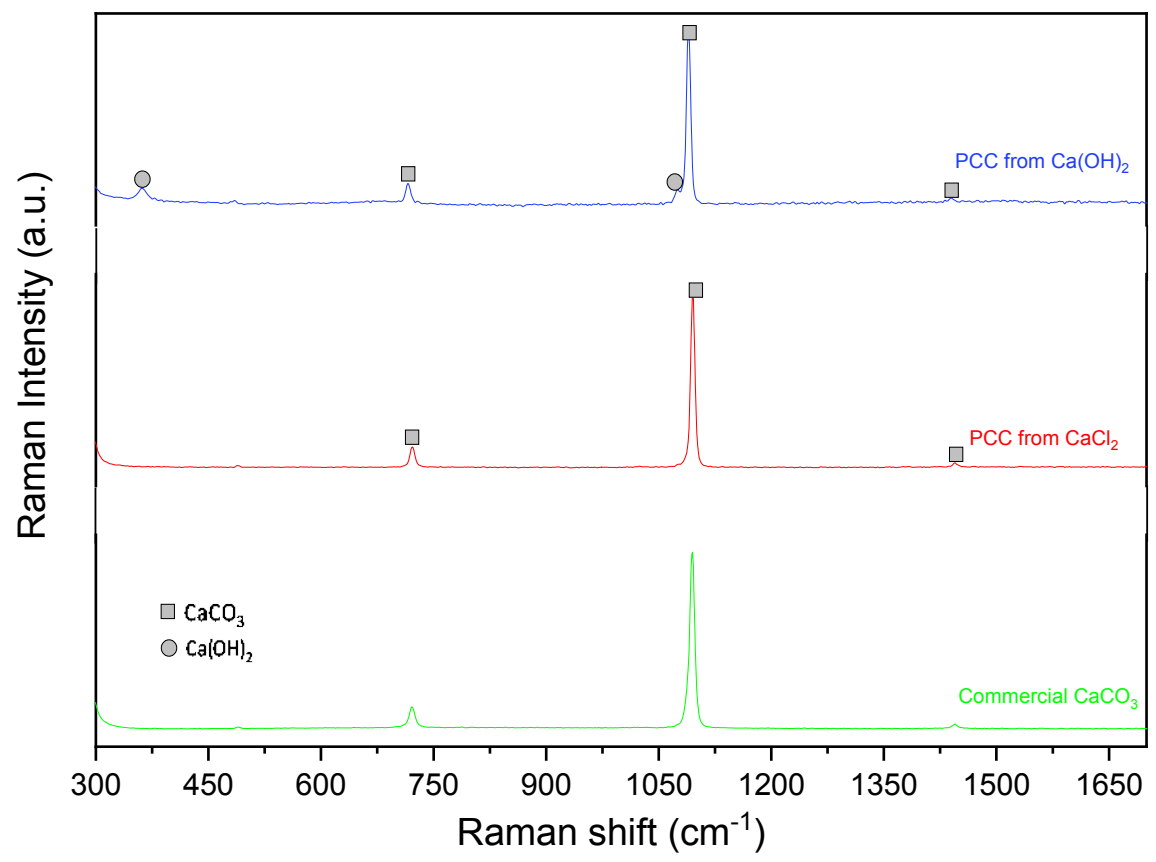

Figure 4. Raman spectra for obtained samples.

This article is protected by copyright. All rights reserved. 


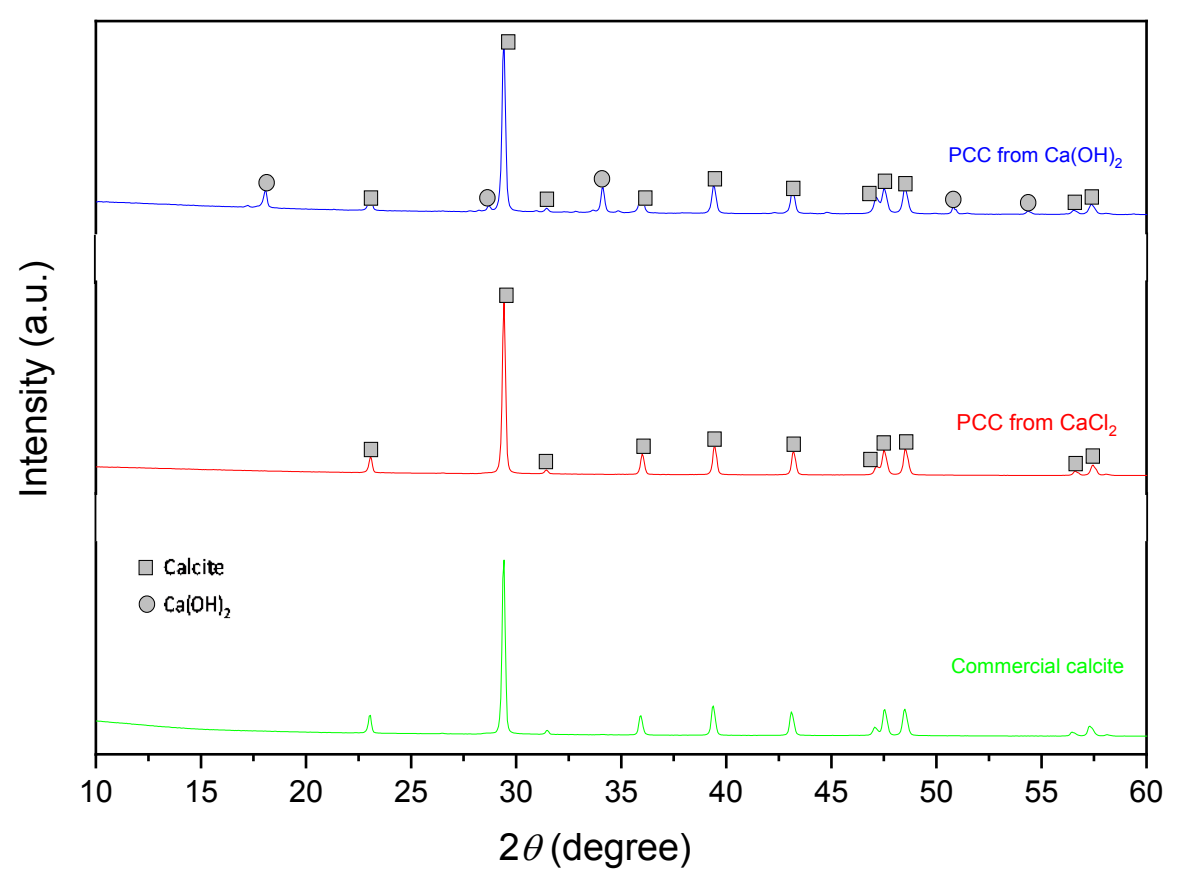

Figure 5. XRD spectra for obtained samples.

This article is protected by copyright. All rights reserved. 


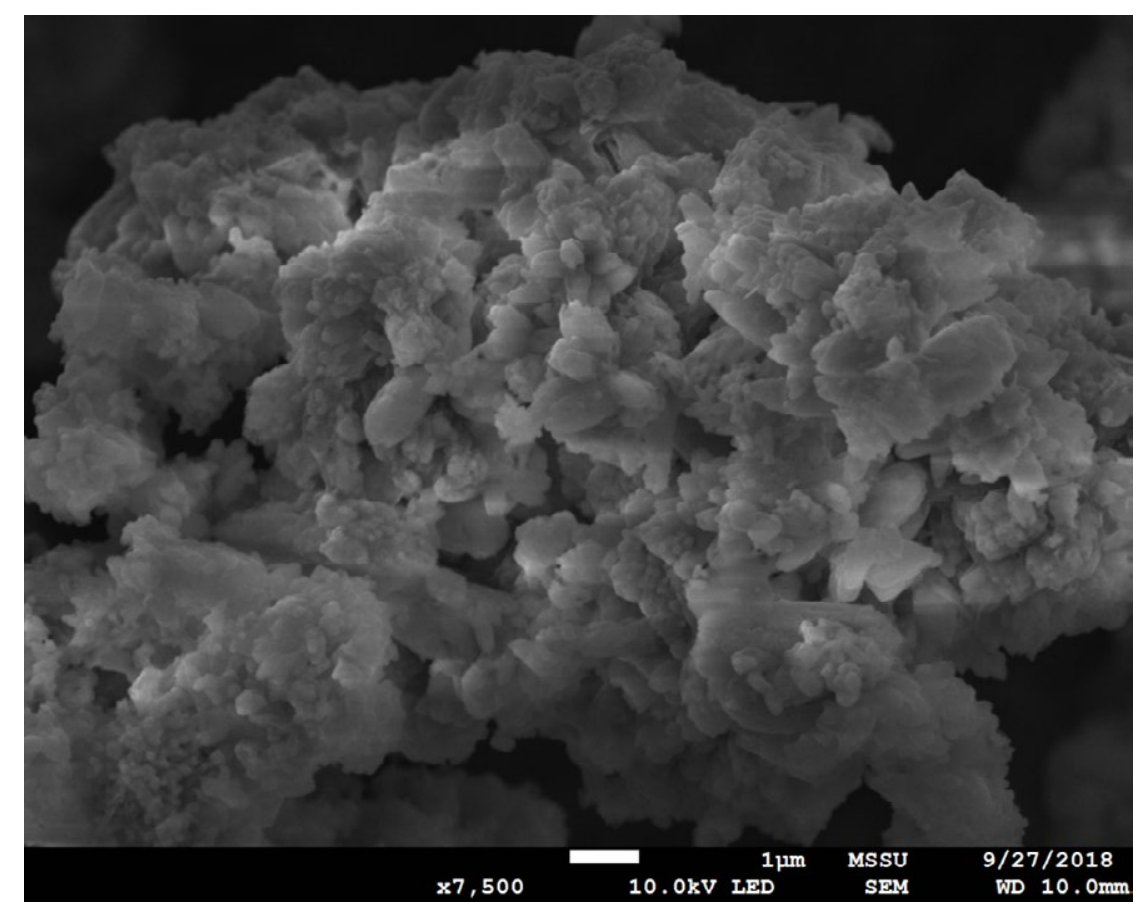

Figure 6. SEM image for PCC from $\mathrm{Ca}(\mathrm{OH})_{2}$. 


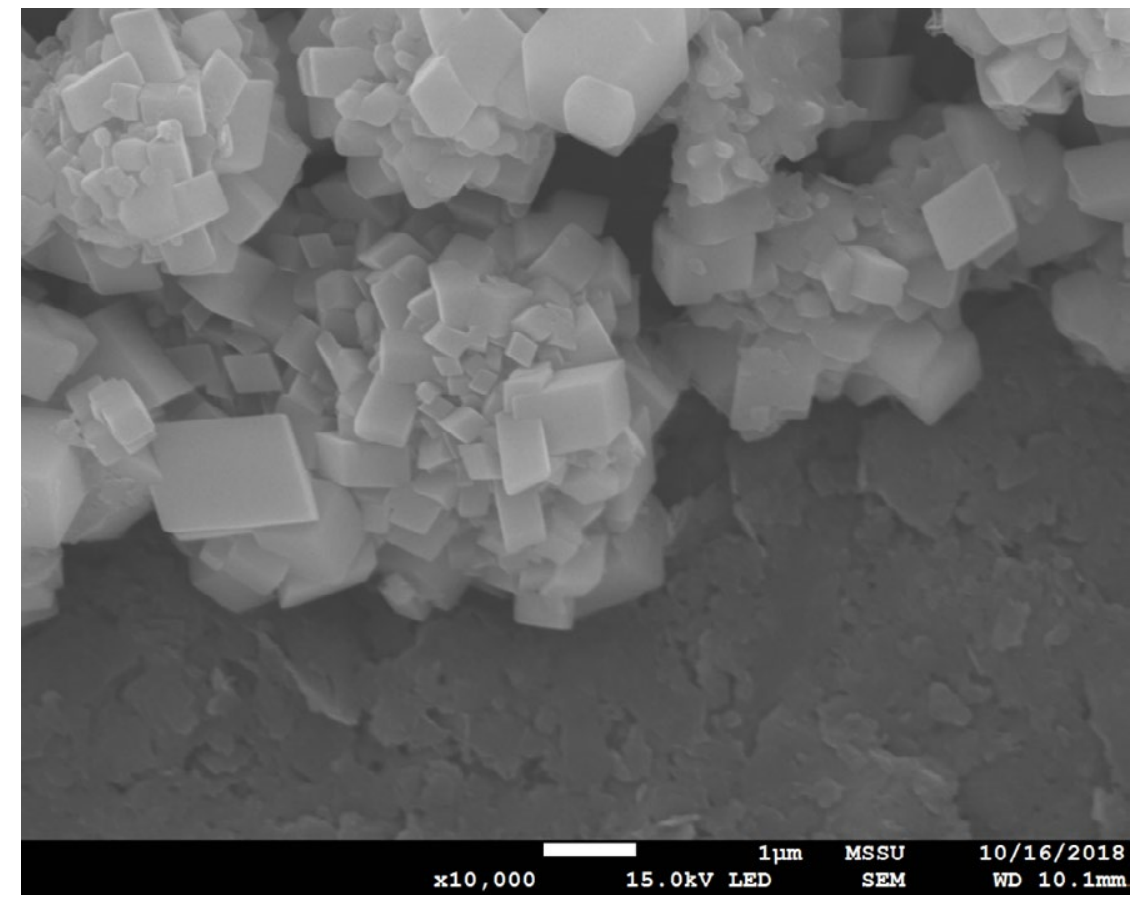

Figure 7. SEM image for $P C C$ from $\mathrm{CaCl}_{2}$. 


\section{References}

1. Datta R, Maher MA, Jones C, Brinker RW. Ethanol-the primary renewable liquid fuel. J Chem Technol Biotechnol 86(4):473-80 (2011).

2. McLaren JS. Future renewable resource needs: Will genomics help? In: Journal of Chemical Technology and Biotechnology, p. 927-32 (2010).

3. Zhou M, Wang H, Hassett DJ, Gu T. Recent advances in microbial fuel cells (MFCs) and microbial electrolysis cells (MECs) for wastewater treatment, bioenergy and bioproducts. J Chem Technol Biotechnol 88(4):508-18 (2013).

4. Zhao Y, Ge Z, Zhang H, Bao J, Sun S. Nutrient removal from biogas slurry and biogas upgrading of crude biogas at high $\mathrm{CO}_{2}$ concentrations using marine microalgae. J Chem Technol Biotechnol 91(4):1113-8 (2016).

5. Wang Z, Zhao Y, Ge Z, Zhang H, Sun S. Selection of microalgae for simultaneous biogas upgrading and biogas slurry nutrient reduction under various photoperiods. J Chem Technol Biotechnol 91(7):1982-9 (2016).

6. Li Y, Merrettig-Bruns U, Strauch S, Kabasci S, Chen H. Optimization of ammonia pretreatment of wheat straw for biogas production. J Chem Technol Biotechnol 90(1):130-8 (2015). 
7. Cheng B, Ge Z, Zhang H, Zhao Y, Sun S, Hu C. Nutrient removal and biogas upgrading by microalgal strains cultured in anaerobic digested starch wastewater. J Chem Technol Biotechnol 91(12):3028-34 (2016).

8. Baena-Moreno FM, Rodríguez-Galán M, Vega F, Vilches LF, Navarrete B. Review: recent advances in biogas purifying technologies. Int J Green Energy . p $1-12(2019)$.

9. Abatzoglou N, Boivin S. A review of biogas purification processes. Biofuels, Bioproducts and Biorefining 3:42-71 (2008).

10. Gao Y, Gu L, Qin Y, Wang X, Wang F. Dicarboxylic acid promoted immortal copolymerization for controllable synthesis of low-molecular weight oligo(carbonate-ether) diols with tunable carbonate unit content. J Polym Sci Part A Polym Chem 50(24):5177-84 (2012).

11. Baena-moreno FM, Rodríguez-galán M, Vega F, Alonso-fariñas B, Arenas LFV, Navarrete B. Carbon capture and utilization technologies : a literature review and recent advances. Energy Sources, Part A Recover Util Environ Eff, p. 1-31 (2018)

12. Baena-Moreno FM, Rodríguez-Galán M, Vega F, Reina TR, Vilches LF, Navarrete B. Regeneration of Sodium Hydroxide from a Biogas Upgrading Unit through the Synthesis of Precipitated Calcium Carbonate: An Experimental Influence Study of Reaction Parameters. Processes 6 (2018).

13. Baciocchi R, Carnevale E, Corti A, Costa G, Lombardi L, Olivieri T, et al. Innovative process for biogas upgrading with $\mathrm{CO}_{2}$ storage: Results from pilot 
plant operation. Biomass and Bioenergy 53: 128-137 (2013).

14. Bauer F, Hulteberg C, Persson T, Tamm D. Biogas upgrading - Review of commercial technologies. Swedish Gas Technol Centre, SGC, p- 82. (2013).

15. Läntelä J, Rasi S, Lehtinen J, Rintala J. Landfill gas upgrading with pilot-scale water scrubber: Performance assessment with absorption water recycling. Appl Energy 92:307-14 (2012).

16. Abdeen FRH, Mel M, Jami MS, Ihsan SI, Ismail AF. A review of chemical absorption of carbon dioxide for biogas upgrading. Chinese J Chem Eng 24(6):693-702 (2016).

17. Zhang Z. Comparisons of various absorbent effects on carbon dioxide capture in membrane gas absorption (MGA) process. J Nat Gas Sci Eng 31: 589-595. (2016).

18. Zhang Z, Chen F, Rezakazemi M, Zhang W, Lu C, Chang H, et al. Modeling of a $\mathrm{CO}_{2}$-piperazine-membrane absorption system. Chem Eng Res Des 131: 375$384(2018)$.

19. Vega F, Cano M, Gallego M, Camino S, Camino JA, Navarrete B. Evaluation of MEA $5 \mathrm{M}$ performance at different $\mathrm{CO}_{2}$ concentrations of flue gas tested at a $\mathrm{CO}_{2}$ capture lab-scale plant. Energy Procedia 114:6222-8 (2017).

20. Vega F, Cano M, Portillo E, Camino S, Camino JA, Navarrete B. Kinetic Characterization of Solvents for $\mathrm{CO}_{2}$ Capture under Partial Oxy-combustion Conditions. In: Energy Procedia, p. 2055-60 (2017). 
21. Sanna A, Vega F, Navarrete B, Maroto-Valer MM. Accelerated MEA degradation study in hybrid $\mathrm{CO}_{2}$ capture systems. In: Energy Procedia, p. 745-9 (2014).

22. Baciocchi R, Carnevale E, Costa G, Gavasci R, Lombardi L, Olivieri T, et al. Performance of a biogas upgrading process based on alkali absorption with regeneration using air pollution control residues. Waste Manag 33(12):2694$2705(2013)$

23. Kismurtono M. Upgrade Biogas Purification in Packed Column with Chemical Absorption of $\mathrm{CO}_{2}$ For Energy Alternative Of Small Industry ( UKM-Tahu ). Int J Eng Technol 11(1):59-62 (2011).

24. Stolaroff JK, Keith DW, Lowry G V. Carbon Dioxide Capture from Atmospheric Air Using Sodium Hydroxide Spray. Environ Sci Technol 42(8):2728-35 (2008).

25. Baciocchi R, Corti A, Costa G, Lombardi L, Zingaretti D. Storage of carbon dioxide captured in a pilot-scale biogas upgrading plant by accelerated carbonation of industrial residues. In: Energy Procedia (2011).

26. Baena-Moreno FM, Rodríguez-Galán M, Vega F, Ramirez-Reina T, Vilches L, Navarrete B. Understanding the influence of the alkaline cation $\mathrm{K}+$ or $\mathrm{Na}+$ in the regeneration efficiency of a biogas upgrading unit. Int J Energy Res 1-8 (2019).

27. Leonzio G. Upgrading of biogas to bio-methane with chemical absorption process: Simulation and environmental impact. J Clean Prod 131: 364-375 (2016).

28. Baciocchi R, Costa G, Lategano E, Marini C, Polettini A, Pomi R, et al. Accelerated carbonation of different size fractions of bottom ash from RDF 
incineration. Waste Manag 30(7):1310-7 (2010).

29. Morone M, Costa G, Polettini A, Pomi R, Baciocchi R. Valorization of steel slag by a combined carbonation and granulation treatment. Miner Eng 59: 82-90 (2014)

30. Librandi P, Costa G, Souza ACB De, Stendardo S, Luna AS, Baciocchi R. Carbonation of Steel Slag: Testing of the Wet Route in a Pilot-scale Reactor. In: Energy Procedia (2017).

31. Said A, Mattila HP, Järvinen M, Zevenhoven R. Production of precipitated calcium carbonate (PCC) from steelmaking slag for fixation of $\mathrm{CO}_{2}$. Appl Energy 112: $765-771(2013)$.

32. Lombardi L, Corti A, Carnevale E, Baciocchi R, Zingaretti D. Carbon dioxide removal and capture for landfill gas up-grading. In: Energy Procedia p. 465-72 (2011).

33. Lombardi L, Carnevale E. Economic evaluations of an innovative biogas upgrading method with $\mathrm{CO}_{2}$ storage. Energy 62:88-94 (2013).

34. Xia J, Eigenberger G, Strathmann H, Nieken U. Flow battery based on reverse electrodialysis with bipolar membranes: Single cell experiments. J Memb Sci 565: 157-168 (2018).

35. Ghyselbrecht K, Silva A, Van der Bruggen B, Boussu K, Meesschaert B, Pinoy L. Desalination feasibility study of an industrial $\mathrm{NaCl}$ stream by bipolar membrane electrodialysis. J Environ Manage 140: 69-75 (2014). 
36. Herrero-Gonzalez M, Diaz-Guridi P, Dominguez-Ramos A, Ibañez R, Irabien A. Photovoltaic solar electrodialysis with bipolar membranes. Desalination 433: 155-163 (2018).

37. Jiang $\mathrm{C}$, Zhang $\mathrm{Y}$, Feng $\mathrm{H}$, Wang $\mathrm{Q}$, Wang $\mathrm{Y}$, Xu T. Simultaneous $\mathrm{CO}_{2}$ capture and amino acid production using bipolar membrane electrodialysis (BMED). $\mathrm{J}$ Memb Sci 542: 264-271 (2017).

38. Ghyselbrecht K, Huygebaert M, Van der Bruggen B, Ballet R, Meesschaert B, Pinoy L. Desalination of an industrial saline water with conventional and bipolar membrane electrodialysis. Desalination 318:9-18 (2013).

39. Baena-moreno FM, Vega F, Reina TR. Regeneration of Sodium Hydroxide from a Biogas Upgrading Unit through the Synthesis of Precipitated Calcium Carbonate: An Experimental Influence Study. Process 6(11):1-12 (2018).

40. Legodi MA, De Waal D, Potgieter JH, Potgieter SS. Technical note rapid determination of $\mathrm{CaCO}_{3}$ in mixtures utilising FT-IR spectroscopy. Miner Eng 14(9): 1107-1111 (2001).

41. Vagenas N V., Gatsouli A, Kontoyannis CG. Quantitative analysis of synthetic calcium carbonate polymorphs using FT-IR spectroscopy. Talanta 59(4): 831$836(2003)$.

42. Dandeu A, Humbert B, Carteret C, Muhr H, Plasari E, Bossoutrot JM. Raman spectroscopy - A powerful tool for the quantitative determination of the composition of polymorph mixtures: Application to $\mathrm{CaCO}_{3}$ polymorph mixtures. Chem Eng Technol 19(2): 221-225 (2006). 
43. Altiner M, Yildirim M. Production of precipitated calcium carbonate particles with different morphologies from dolomite ore in the presence of various hydroxide additives. Physicochem Probl Miner Process 53(1): 413-426 (2017).

44. Dawson P, Hadfield CD, Wilkinson GR. The polarized infra-red and Raman spectra of $\mathrm{Mg}(\mathrm{OH})_{2}$ and $\mathrm{Ca}(\mathrm{OH})_{2}$. J Phys Chem Solids 34(7): 1217-1225 (1973).

45. Ahn JW, Kim JH, Park HS, Kim JA, Han C, Kim H. Synthesis of single phase aragonite precipitated calcium carbonate in $\mathrm{Ca}(\mathrm{OH})_{2}-\mathrm{Na} 2 \mathrm{CO}_{3}-\mathrm{NaOH}$ reaction system. Korean J Chem Eng 22(6): 852-856 (2005).

46. Kontoyannis CG, Vagenas N V. Calcium carbonate phase analysis using XRD and FT-Raman spectroscopy. Analyst 125: 251-255 (2000).

47. Gunasekaran S, Anbalagan G, Pandi S. Raman and infrared spectra of carbonates of calcite structure. J Raman Spectrosc 37(9): 892-899 (2006).

48. Khachani M, El Hamidi A, Halim M, Arsalane S. Non-isothermal kinetic and thermodynamic studies of the dehydroxylation process of synthetic calcium hydroxide $\mathrm{Ca}(\mathrm{OH})_{2}$. J Mater Environ Sci 5(2): 615-624 (2014).

49. Uriarte LM, Dubessy J, Boulet P, Baonza VG, Bihannic I, Robert P. Raman spectra of synthesized $\mathrm{CaCl}_{2} \cdot \mathrm{nH}_{2} \mathrm{O}$ solids $(\mathrm{n}=0,2,4,6)$. J Raman Spectrosc 46(10):822-828 (2015).

50. Murnandari A, Kang J, Youn MH, Park KT, Kim HJ, Kang SP, et al. Effect of process parameters on the $\mathrm{CaCO}_{3}$ production in the single process for carbon capture and mineralization. Korean J Chem Eng 34(3):935-941 (2017). 


\section{Tables}

Table 1. Specifications of the chemicals.

\begin{tabular}{cccc} 
Name & CAS no. & Source & Purity (mass fraction) \\
\hline $\mathrm{Ca}(\mathrm{OH})_{2}$ & $1305-62-0$ & PanReac-AppliChem & $>0.99$ \\
$\mathrm{CaCl}$ & $10043-52-4$ & PanReac-AppliChem & $>0.99$ \\
$\mathrm{CaCO}_{3}$ & $471-34-1$ & PanReac-AppliChem & $>0.99$ \\
$\mathrm{Na}_{2} \mathrm{CO} 3$ & $497-19-8$ & PanReac-AppliChem & $>0.99$
\end{tabular}

This article is protected by copyright. All rights reserved. 
Table 2. FTIR vibration bands for the chemicals studied.

\begin{tabular}{|c|c|c|}
\hline Spectrum & Wavenumber of main bands $\left(\mathrm{cm}^{-1}\right)$ & Uncertainty \\
\hline 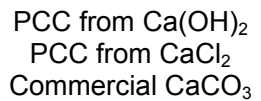 & $\begin{array}{l}1430,876,715 \\
1430,876,715 \\
1430,876,715\end{array}$ & $\begin{array}{l} \pm 2 \% \\
\pm 2 \% \\
\pm 2 \%\end{array}$ \\
\hline
\end{tabular}

This article is protected by copyright. All rights reserved. 
Table 3. Raman bands for the chemicals studied.

\begin{tabular}{|c|c|c|}
\hline Spectrum & Raman shift $\left(\mathrm{cm}^{-1}\right)$ & Uncertainty \\
\hline $\begin{array}{l}\mathrm{PCC} \text { from } \mathrm{Ca}(\mathrm{OH})_{2} \\
\mathrm{PCC} \text { from } \mathrm{CaCl}_{2} \\
\text { Commercial } \mathrm{CaCO}_{3}\end{array}$ & $\begin{array}{c}400,732,1086,1100,1435 \\
732,1100,1435 \\
732,1100,1435\end{array}$ & $\begin{array}{l} \pm 1 \% \\
\pm 1 \% \\
+1 \%\end{array}$ \\
\hline
\end{tabular}

This article is protected by copyright. All rights reserved. 
Table 4. XRD peaks for the chemicals studied.

PCC from $\mathrm{Ca}(\mathrm{OH})_{2} \quad 18,23,28,32,34,36,39,43,46,47,48,51,55,57,58$ 